\title{
Nutrient inputs from seabirds and humans on a populated coral cay
}

\author{
Jonathan Staunton Smith, Craig R. Johnson \\ Zoology Department, The University of Queensland, St. Lucia, Queensland 4072, Australia
}

\begin{abstract}
Inputs of inorganic nutrients in 1992 from seabirds (white-capped noddy and wedgetail shearwater, maximum of ca 80000 breeding pairs) are compared to inputs from humans 197700 person days) on Heron Island at the southern end of the Great Barrier Reef, Australia. We estimated that noddies deposited ca $107 \mathrm{t}$, and shearwaters ca $22 \mathrm{t}$, of fresh guano. The composition of fresh noddy guano was $7.3 \%$ nitrogen, $1.5 \%$ phosphorus, $60 \%$ moisture and $31.2 \%$ other substances. Assuming a similar composition for shearwaters, the total annual deposition of guano contained $9.4 \mathrm{t}$ nitrogen and $1.9 \mathrm{t}$ phosphorus. Experiments examining effects of ageing of guano indicated a large decrease in total nitrogen in guano under humid conditions over $4 \mathrm{~d}$ as a result of volatılısation of $\mathrm{NH}_{3}$. Under natural conditions most of the deposited nitrogen is likely to be lost as $\mathrm{NH}_{3}$ and a relatively small fraction of the soluble component leached into the cay, but the precise dynamics will depend on rainfall and wind patterns. Phosphorus was not volatilised from guano under any experimental conditions. Although inputs of nitrogen and phosphorus from human sewage into the cay system (ca $0.3 \mathrm{t}$ of each) were much less than that from birds, all nutrients from humans are released in liquic form and percolate directly into the cay. Significant seasonal and tidal variations in standing concentrations of $\mathrm{NH}_{3}$, oxidised forms of nitrogen $\left(\mathrm{NO}_{2}+\mathrm{NO}_{3}\right)$, and $\mathrm{PO}_{4}$ were detected in the water column around the island. Trends of higher mean concentrations of all nutrients in summer than in winter, and higher concentrations at low tide than at high tide except at sites close to the island where nutrient levels were high independent of tide, suggest that nutrients may be transported from guano on Heron lsland into the water immediately surrounding the island. The exact fate and mechanisms of transport of all nutrients require further attention.
\end{abstract}

KEY WORDS: Seabirds Guano S Sewage Inorganic nutrients - Eutrophication - Coral reefs

\section{INTRODUCTION}

Eutrophication of coral reefs is a matter of increasing concern for management authorities (e.g. Kelleher 1988, Wilkinson 1993). High levels of added nutrients (usually nitrogen and phosphorus) can have direct toxic effects on corals by hindering calcification (Kinsey \& Davies 1979, Rasmussen 1988) and can directly or indirectly mediate changes in community structure from coral- to algal-dominated (Smith et al. 1981, Kinsey 1988). In the Great Barrier Reef Marine Park in Australia, increases in tourism (Ottesen 1988), leaching of naturally derived nutrients (Prove 1988), and leaching of fertilisers used in terrestrial agriculture (Rasmussen 1988) have led to elevation of the extraneous input of nutrients into coral reef systems along the coast of Queensland (see also Bell 1992). However little attention has been paid to the potential for fertilisation of coral reefs with nutrients from the breeding sites of seabirds.

Seabirds that nest on coral cays concentrate nitrogen and phosphorus from surrounding waters and deposit these nutrients onto cays in the form of guano, which is high in both nitrogen and phosphorus (e.g. Hutchinson 1950). Thus, coral cays with large populations of seabirds are potentially sources for localised chronic eutrophication, providing that mechanisms exist to transport deposited nutrients to the surrounding waters. Studies of seabird colonies on rocky shores have found that nutrient concentrations in adjacent waters are significantly greater than those at sites remote from colonies (Bédard et al, 1980, Lindenboom 
1984, Bosman \& Hockey 1986). However, unlike on rocky shores, the majority of rain that falls on coral cays does not wash directly into the surrounding waters but seeps through the porous matrix of the cay into the groundwater. Exchange of groundwater with standing water around cays might follow events such as heavy rainfall and tidal oscillations. However, many biological, chemical and physical processes act on guano after it is deposited to alter the quantity and type of nutrients available, and influence the site at which nutrients are released (Copeman \& Dillman 1937, Riley \& Chester 1971, Bosman et al. 1985, Furnas $1988,1990, D^{\prime}$ Elia \& Wiebe 1990, Krol et al. 1992). The important point is that it cannot be assumed that the occurrence of large colonies of seabirds on coral cays implies significant transport of nutrients into adjacent waters.

Heron Island on the Great Barrier Reef supports large populations of both birds and humans, the latter at a resort and research station which cater for several thousand visitors annually. Sewage waste from the resort is treated to secondary levels, and that from the research station is disposed of via a septic system, but the amounts of human-derived nitrogen and phosphorus entering the cay system have not been estimated.

Populations of the 2 most abundant birds on the island have increased dramatically during the past several decades (Barnes \& Hill 1989, Hill \& Barnes 1989 ) so that in the summer breeding season of $1992 \mathrm{ca}$ 63000 pairs of white-capped noddies Anous minutus and ca 16500 pairs of wedgetail shearwaters Puffinus pacificus roosted on the island (J. Ogden unpubl. data). Both species of bird effect exogenous input of nutrients rather than direct recycling of reef-derived material since they normally feed away from the reef during the day and return to the island in the late afternoon.

Allaway \& Ashford (1984) estimated that ca $45 \mathrm{t}$ of (dry) matter was deposited by seabirds onto Heron Island in 1983, however this estimate needs qualifying since (1) no attempt was made to estimate the substantial amount of guano intercepted by foliage, (2) chemical analyses and estimates of input of nutrients were undertaken on samples of guano contaminated with other material, e.g. sand, feathers and plant material, (3) the age of guano that was analysed varied from 0 to $3 \mathrm{~d}$, which assumes that there is no change in the composition of nutrient species in guano over a 3 day period, (4) it was not determined whether oven-drying guano altered the chemistry of samples, and (5) no attempt was made to investigate the soluble fraction of guano that could leach into groundwater.

The aims of this study were to (1) estimate and compare the amount of human-and bird-derived nitrogen and phosphorus deposited onto Heron Island during 1992, (2) facilitate predictions of the fate of nutrients by investigating changes in the nutrient composition of guano after its deposition in ambient, dry, and humid atmospheres, and (3) search for broad-scale nutrient signals in the waters surrounding Heron Island and examine their relationship with rainfall, season, tidal cycle and distance from the island.

\section{MATERIALS AND METHODS}

Study site. The work was undertaken on Heron Island $\left(23^{\circ} 27^{\prime} \mathrm{S}, 151^{\circ} 55^{\prime} \mathrm{E}\right)$ at the southern end of the Great Barrier Reef during February-September 1992. The island is a coral cay (ca $800 \times 200 \mathrm{~m}$ ) and hosts a resort, a research station and a national park. Much of the island is covered by forest consisting largely of Pisonia grandis which provides nesting sites for noddies, while the shearwaters nest in burrows on the forest floor.

Nutrients in guano: effects of atmosphere and ageing. Noddy guano was collected fresh onto sheets of cellulose-acetate drawing film pinned to platforms in areas where deposition rates were high (to minimise collection time). The mean weight of a fresh dropping was estimated from 180 droppings weighed individually.

To examine the effect of atmospheric humidity and ageing of droppings on nutrient content, a total of ca $18 \mathrm{~g}$ of fresh droppings was collected on 2 consecutive afternoons in June. Droppings from the first afternoon were kept cool in a sealed container in the dark, and then combined with droppings from the second collection and homogenised. Low precision in determining nutrient levels in single droppings required that a large number of droppings be pooled instead of using individual replicate droppings. The resulting mass was divided into 20 samples of known fresh weight 1 sample was oven-dried at $50^{\circ} \mathrm{C}$ for $48 \mathrm{~h}$ to estimate the moisture content of fresh guano, 1 sample was processed immediately to determine nutrient levels in fresh guano, while the other 18 samples were subjected to 1 of 3 treatments of humidity at room temperature, viz. dry (samples maintained in a 3 I sealed container with silica-gel drying agent), humid (samples maintained in a 3 l sealed container with excess water), and ambient (open container) atmospheres. Samples were analysed for soluble and insoluble nutrients after $1,4,7,14$ or $28 \mathrm{~d}$.

For nutrient analyses, samples were mixed with analytical water and their $\mathrm{pH}$ determined. Each sample was prefiltered (Whatman glass fibre, preweighed) and then filtered $(0.45 \mu \mathrm{m}$ cellulose acetate, preweighed). The filtrate was frozen and the soiled prefilter and filters frozen and freeze-dried. All samples were kept frozen until delivery to the Queensland 
Government Chemical Laboratory for analysis of solid and soluble fractions.

Concentrations of ammonia $\left(\mathrm{NH}_{3}\right)$, nitrite $\left(\mathrm{NO}_{2}\right)$, total oxidised nitrogen (OXN), total soluable Kjeldahl nitrogen (TKN $\mathrm{Tol}_{\text {sol }}$ ), total soluble phosphorus $\left(\mathrm{TP}_{\text {sol }}\right)$, and orthophosphate $\left(\mathrm{PO}_{4}\right)$ were determined for the filtrates. Total insoluble Kjeldahl nitrogen ( $\mathrm{TKN}_{\text {insol }}$ ) and total insoluble phosphorus $\left(\mathrm{TP}_{\text {Insol }}\right)$ were determined for the freeze-dried solids. Other forms of nitrogenous and phosphorous compounds were calculated as:

$$
\begin{aligned}
& \mathrm{ON}_{\text {1nsol }}=\mathrm{TKN}_{\text {1nsol }} \\
& \mathrm{ON}_{\text {sol }}=\mathrm{TKN} \text { sol }-\mathrm{NH}_{3} \\
& \mathrm{NO}_{3}=\mathrm{OXN}-\mathrm{NO}_{2} \\
& \mathrm{TN}=\mathrm{TKN} \text { sol }+\mathrm{OXN}+\mathrm{TKN}_{\text {1nsol }} \\
& \mathrm{TP}=\mathrm{TP}_{\text {sol }}+\mathrm{TP}_{\text {insol }}
\end{aligned}
$$

where $O N_{1 n s o l}=$ total insoluble organic nitrogen, $O N_{\text {sol }}$ = total soluble organic nitrogen, $\mathrm{TN}=$ total nitrogen, and $\mathrm{TP}=$ total phosphorus. Nutrient content was calculated as percentage of wet weight of the guano sample.

Size of bird populations. Noddies: The number of noddies on the island was determined at hourly intervals over 12 to $24 \mathrm{~h}$ on each of $6 \mathrm{~d}$ (February 4, 16, 29, March 11, June 26, August 15) using 2 methods.

Method 1 (February and March): The mean number of birds per nest at time $t\left(B_{t}\right)$ was calculated $( \pm \mathrm{SE})$ at hourly intervals for 8 separate trees, viz. 6 Pandanus pedunculatus, 1 Argusia argentia and 1 Pisonia grandis. $P$. pedunculatus was favoured because it was easier to count roosting birds at night in this species than in $P$. grandis and $A$. argentia. All birds and all nests, regardless of occupancy, were counted in each of the 8 trees. Therefore $T B_{t}=B_{t} N$ where $T B_{t}=$ the total number of birds on the island at time $t$ and $N=$ the total number of nests (active plus inactive). We assumed $\mathrm{N}=$ 72921 (J. Ogden pers. comm.; data from January survey, 1992)

Method 2 (June and August): During June and August noddies perched only in trees in the Pisonia forest. Two $30 \times 30 \mathrm{~m}$ quadrats were set out in the $P$. grandis forest (the sites used by Ogden 1979), and birds perched in trees originating inside the quadrats were counted at hourly intervals $\left(Q 1_{t}, Q 2_{t}\right)$. Noddies were also counted in two $50 \times 50 \mathrm{~m}$ clearings in the forest $\left(C 1_{t}, C 2_{t}\right)$ because they aggregated in these areas at higher densities than in the forest. The total area of $P$. grandis forest occupied by noddies, estimated from an aerial photograph (1983) was 3.5 ha, not including the 2 clearings. Thus

$$
T B_{t}=\left[\left(Q 1_{t}+Q 2_{t}\right) \times 35000 / 1800\right]+C 1_{t}+C 2 .
$$

Changes in the population size of noddies were assumed to be linear between sampling occasions. Prior to the first sample in February it was assumed that the population had increased linearly from August 15 , 1991, from a level identical to that on August 15, 1992. Similarly, the population after the last sample in August was assumed to increase linearly until February 4, 1993, to attain a level identical to that on February 4, 1992. In June and August birds were unable to be counted after dark in the Pisonia grandis forest. For these samples it was assumed, based on our $24 \mathrm{~h} \mathrm{ob-}$ servations earlier in the year, that the number of noddies on the island reached a maximum at 23:00 h and that the number of birds on the island at this time was $40 \%$ larger than the number at sunset (times of sunrise and sunset were obtained from the star almanac for 1992; Science and Engineering Research Council 1992). The population was assumed to remain constant until 04:00 h the following day and then decrease linearly to the first recorded observation for that day.

Shearwaters: The population size of shearwaters in the 1991-1992 breeding season (January 1992) was estimated at ca 16500 breeding pairs (J. Ogden unpubl. data). We assumed the population increased to its maximum of 33000 by October 14 and remained until mid May, when they all migrated. We assumed that shearwaters migrated daily, leaving the island at dawn and returning $2 \mathrm{~h}$ after sunset (J. Staunton Smith \& J. Kikkawa pers. obs.).

Defecation rates of noddies. Droppings were collected on sheets of black plastic pegged to the ground beneath Pandanus pedunculatus trees. $P$. pedunculatus is well suited for this purpose since there is a lack of low foliage to intercept guano, unlike the Pisonia grandis trees where large amounts of guano collect on the leaves. At hourly intervals over a $24 \mathrm{~h}$ period the number of birds above the plastic $\left(P_{t}\right)$ and the number of new droppings on the sheet $\left(D_{1}\right)$ were counted. The rate of defecation at time $t\left(R_{t}\right)=D_{t} /\left[\left(P_{t}+P_{t-1}\right) / 2\right]$. Defecation rates expressed as total mass of droppings bird $^{-1}$ (unit time) ${ }^{-1}$ were obtained by scaling the number of droppings by the average mass of a single dropping. Rates of defecation were monitored on 3 occasions in summer, but no seasonal data were obtained since birds did not perch in $P$. pedunculatus trees during winter.

Defecation rates of shearwaters. Defecation rates of shearwaters cannot be observed easily since they spend most of the time in burrows while on land. Thus defecation rates were estimated assuming an allometric relationship with the rates measured for noddies and that the daily defecation pattern was the same for both species. Thus

$$
D R_{\mathrm{SW}}=D R_{\mathrm{N}} \times M_{\mathrm{SW}}^{b} / M_{\mathrm{N}}^{b}=2.2 \times D R_{\mathrm{N}}
$$

where $D R_{\mathrm{SW}}$ and $D R_{\mathrm{N}}$ are defecation rates of shearwaters and noddies respectively; $M_{\mathrm{SW}}$ is average mass of 
a shearwater $\left(350 g_{i}\right.$ Serventy et al. 1971), $M_{N}$ is average mass of a noddy (100 g; Serventy et al. 1971), and $b$ is 0.63 which is the scaling factor for rates of ingestion by birds (Peters 1983).

Total input of nutrients in fresh guano. Hourly 100:00 to 23:00 h, determined on 6 days: February 4, 16, 29, March 11, June 26, August 15), daily (from February to August) and yearly (1992) inputs of total fresh guano onto the island were modelled separately for noddies and shearwaters. Amounts of fresh guano were converted to quantities of nutrients on the basis of the nutrient levels in fresh droppings. Hourly inputs were estimated from the product of the number of birds on the island and the defecation rate expressed as mass of droppings bird ${ }^{-1} \mathrm{~h}^{-1}$. Total daily input of guano ( $g$ fresh weight), was calculated as the sum of the 24 hourly inputs. Estimates of daily input for days between samples were made assuming linear changes in daily input. The annual input of bird-derived nutrients in 1992 ( $\mathrm{g}$ fresh weight) was estimated as the sum of all 365 daily inputs.

Inputs of nutrients from humans. Daily inputs of human-derived nutrients (total nitrogen and total phosphorus) from the resort and research station (February to August 1992) were calculated separately as the product of the total number of residents, concentration of nutrients in effluent $\left(\mathrm{mg} \mathrm{I}^{-1}\right.$ ) and flow rate of effluent ( 1 person ${ }^{-1} \mathrm{~d}^{-1}$ ). The 2 were treated separately since the resort operates a sewage treatment plant (secondary treatment only) while the research station uses a septic system. The concentrations of nitrogen and phosphorus in the sewage effluent were assumed constant at 11.8 and $16.7 \mathrm{mg} \mathrm{l}^{-1}$ respectively (means from 2 sewage-plant-performance reports; Anon $1992 \mathrm{a}, \mathrm{b})$, and concentrations of nitrogen and phosphorus in septic effluent were assumed constant at 40.5 and $14.5 \mathrm{mg} \mathrm{l}^{-1}$ respectively (medium strength effluent from domestic septic systems; Canter \& Knox 1985). The average effluent flow for an urban sewage treatment plant is approximately $300 \mathrm{l}_{\text {person }}{ }^{-1} \mathrm{~d}^{-1}$ (P. Bell pers. comm.). However, since water conservation practice on Heron Island reduces influent to lower levels than for urban plants, we assumed a conservative total of 200 I effluent person ${ }^{-1} \mathrm{~d}^{-1}$ from both the resort treatment plant and research station septic systems. Inputs from humans on days when population data were not ob-tained were based on averages from the days when the data were obtained. Total annual input for 1992 was calculated by summing the 365 daily inputs.

Standing concentrations of nutrients in reef waters. Water samples were collected at high and low tides, from the surface and 3 to $10 \mathrm{~cm}$ above the sediment/ water interface ( $=$ bottom samples) in each of 5 zones along each of 4 transects perpendicular to the island perimeter and extending from the centre of the island in NNE, ESE, SSW and WNW directions (Zone $1=10$ $\mathrm{m}$ from the beach at low tide, Zone $2=100 \mathrm{~m}$ from the beach at low tide, Zone 3 = halfway between the beach and the reef crest, Zone 4 = reef crest, Zone $5=$ deep water beyond the reef crest). Zones 3 to 5 on the transect that ran through the lagoon were not included in data analyses due to their extreme distance from the island ( 4 to $9 \mathrm{~km}$ ).

A total of 182 water samples were collected representing all possible combinations of season (summer and winter) and rainfall (before and after heavy rainfall). Replicate samples within any one time/zone/ depth/transect combination were not taken since the results of a pilot study indicated minimal variation in samples taken from the same site at the same time. Zones 1 and 2 only were sampled over 24 to $72 \mathrm{~h}$ towards the end of and after $143 \mathrm{~mm}$ of rain over $2 \mathrm{~d}$ in summer and after $22 \mathrm{~mm}$ of rain in a $24 \mathrm{~h}$ period in winter. Water samples werewas filtered through $0.45 \mu \mathrm{m}$ cellulose acetate filters and frozen immediately. Frozen samples were delivered to the Government Chemical Laboratory for determination of concentrations of $\mathrm{NH}_{3}, \mathrm{OXN}$ and $\mathrm{PO}_{4}$.

Statistical analyses. Statistical analyses were carried out using the SAS software package. ANOVA models were used to test the significance of differences in standing concentrations of nutrients due to the effects of zone, rain, tide, season and position in the water column (all fixed effects). The effect of transect was included in all models but was not tested as there was no replication within transects (transect is a random effect, since although transects were orientated at $90^{\circ}$ to each other, the arrangement could be rotated anywhere through $360^{\circ}$ ). Error mean squares used in Ftests were 'main effect $x$ transect' for main effects and 'interaction effect $\times$ transect' for interactions. Data were log-transformed to stabilise variances. Tests for the effect of rain compared Zones 1 and 2 only. Tukey's HSD comparisons (Day \& Quinn 1989) were undertaken to determine the nature of significant results. Alpha (rate of type I error) was set at 0.1 given the low power.

\section{RESULTS}

\section{Nutrients in guano}

Nutrients in fresh guano

The average fresh weight of a dropping was $0.05 \pm$ 0.004 (SE) $g$. The moisture content of guano accounted for $60.0 \%$ of its fresh weight. Nitrogen and phosphorus accounted for $7.3 \%$ and $1.5 \%$ of fresh weight respectively, with $67.7 \%$ of the nitrogen occurring as soluble 


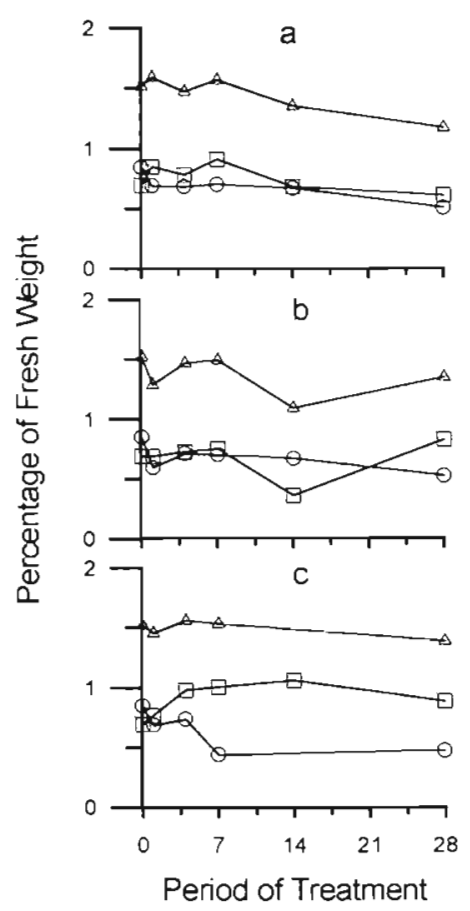

(Days)

Fig. 1. Anous minutus. Temporal changes in content of phosphorus species in guano samples (\% of fresh weight) in (a) ambient, (b) dry and (c) humid environments. Samples were from a single stock of homogenised noddy guano. () Total insoluble phosphorus; $(0) \mathrm{PO}_{4}-\mathrm{P} ;(\Delta)$ total phosphorus

organic nitrogen, $15.2 \%$ as $\mathrm{NH}_{3}$, and $17.1 \%$ as insoluble organic nitrogen. Oxidised forms of nitrogen constituted a negligible percentage of fresh guano. Of the phosphorus in fresh guano, $54.5 \%$ occurred as $\mathrm{PO}_{4}$, with the remainder as insoluble phosphorus.

\section{Effect of humidity and ageing of guano on phosphorus species}

In all 3 humidity treatments the total phosphorus content of guano ( $\left.\mathrm{TP}_{\text {insol }}+\mathrm{PO}_{4}\right)$ decreased only slightly with time to $28 \mathrm{~d}$ after deposition (Fig. 1). The principal difference among humidity treatments was that the concentration of the insoluble fraction was much higher than the soluble $\left(\mathrm{PO}_{4}\right)$ in the humid environment, but in ambient and dry humidity atmospheres, $\mathrm{TP}_{\text {sol }}$ and $\mathrm{TP}_{\text {insol }}$ were similar.

\section{Effect of humidity and ageing of guano on nitrogen species}

Since most of the nitrogen occurred in soluble organic form $\left(\mathrm{ON}_{\mathrm{sol}}\right)$ in all 3 humidity treatments,

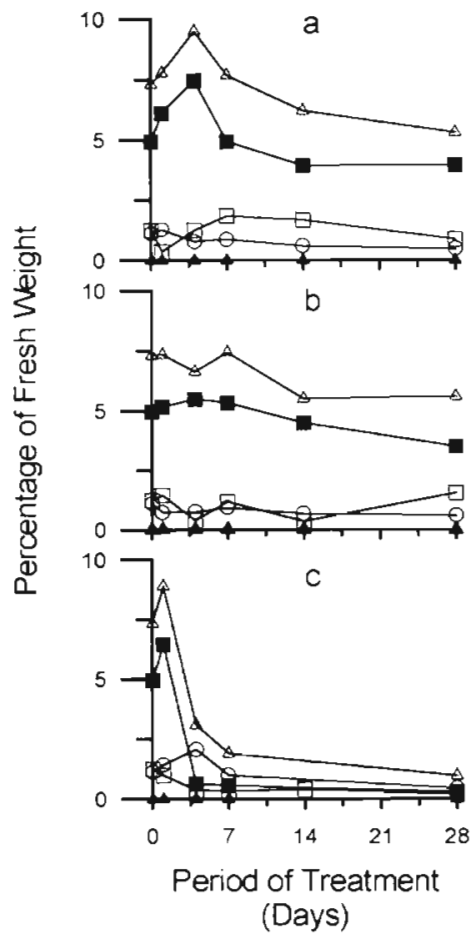

Fig. 2. Anous minutus. Temporal changes in content of nitrogen species in guano samples (\% of fresh weight) in (a) ambient, (b) dry and (c) humid environments. Samples were from a single stock of homogenised noddy guano. (a) Insoluble organic nitrogen; (O) $\mathrm{NH}_{3}-\mathrm{N}_{i}$ (ム) OXN; (a) soluble organic nitrogen; $(\Delta)$ total nitrogen

changes in total nitrogen (TN) paralleled closely those of $\mathrm{ON}_{\text {sol }}$ (Fig. 2). However, atmospheric moisture levels had a considerable effect on rates of change of most nitrogen species in guano. The exception was total oxidised nitrogen (OXN) which occurred in negligible but variable amounts in all samples in all atmospheric conditions.

The most dramatic reductions in the concentration of all forms of nitrogen in guano after deposition occurred in the high humidity treatment (Fig. 2c). Although levels of $\mathrm{ON}_{\text {sol }}$ increased by $30.4 \% 24 \mathrm{~h}$ after deposition, they were greatly decreased by Day 4 , and after $28 \mathrm{~d}$ only $6.0 \%$ of the initial $\mathrm{ON}_{\text {sol }}$ remained. Similarly, $\mathrm{ON}_{\mathrm{insol}}$ and $\mathrm{TN}$ decreased by 82.5 and $86.8 \%$ respectively in $28 \mathrm{~d}$. Four days after deposition, levels of $\mathrm{NH}_{3}$ increased by $85.5 \%$, but decreased to 90.2 and $40.1 \%$ of initial $\mathrm{NH}_{3}$ after 7 and $28 \mathrm{~d}$ respectively.

In the ambient atmosphere $\mathrm{ON}_{\text {sol }}$ increased by $23.5 \%$ after $1 \mathrm{~d}$ and by $50.6 \%$ after $4 \mathrm{~d}$ before decreasing to $79.9 \%$ of the original levels by Day 28 (Fig. 2a). A similar pattern occurred in $\mathrm{TN}$, but the rate of decrease over $28 \mathrm{~d}$ was greater (to $72.4 \%$ of $\mathrm{TN}_{\text {fresh guano }}$ ) since amounts of both $\mathrm{NH}_{3}$ and $\mathrm{ON}_{\text {nnsol }}$ also decreased with time (to 57.9 and $30.3 \%$ of the quantities in fresh guano respectively). 
The trends in the dry atmosphere were similar to those at ambient conditions, although the initial increase in $\mathrm{ON}_{\text {sol }}$ was not as pronounced (Fig. 2b). Total $\mathrm{N}$ decreased by $24.6 \%$ after $14 \mathrm{~d}$ exposure but remained stable until the end of the experiment, and amounts of $\mathrm{ON}_{\text {sol }}$ declined by $29.4 \%$ after $28 \mathrm{~d}$. No clear trend was evident in $O N_{\text {insol }}$ which varied around $1 \%$ of the fresh weight of guano. In the dry atmosphere, $\mathrm{NH}_{3}$ in aged guano (of any age) was less than in fresh guano.

$$
\mathrm{pH} \text { of guano }
$$

In the dry and ambient atmospheres there was little change in the initial $\mathrm{pH}_{\text {fresh }}$ of 6.8 over $28 \mathrm{~d}$ (Fig. 3). In contrast, samples became alkaline in the humid treatment by Day 4 ( $\mathrm{pH}=8.2$ to 8.5 ) and remained so for the duration of the experiment.

\section{Daily and seasonal changes in bird populations in 1992}

\section{Noddies}

Noddies demonstrated strong diurnal migrations; greatest numbers of resident birds were recorded at night and lowest numbers were recorded during daylight (Fig. 4). Large seasonal changes also occurred; assuming the estimate for 23:00 hours to indicate total population size, the population decreased by ca $40 \%$ from February to mid March. By June and August the population had declined to ca $3 \%$ of the maximum population recorded in summer.

\section{Shearwaters}

Ogden (unpubl.) estimated ca 16500 breeding pairs of shearwaters roosted on the island in January 1992. We assumed this population was maintained from mid October to mid May, and that during their residency, shearwaters leave the island at dawn and return $2 \mathrm{~h}$ after sunset (based on Kikkawa 1970).

\section{Defecation rates}

Defecation rates of noddies peaked at 19:00 h at $13.17 \pm 0.6$ droppings bird ${ }^{-1} \mathrm{~h}^{-1}$ (Fig. 5). At an average of $0.05 \pm 0.004 \mathrm{~g}$ dropping ${ }^{-1}$ this equates to $0.65 \mathrm{~g}$ fresh guano bird ${ }^{-1} \mathrm{~h}^{-1}$ at 19:00 h. The lowest rates of defecation were between 02:00 and 05:00 h at ca 1 dropping bird $^{-1} \mathrm{~h}^{-1}$. Hourly rates of defecation for shearwaters

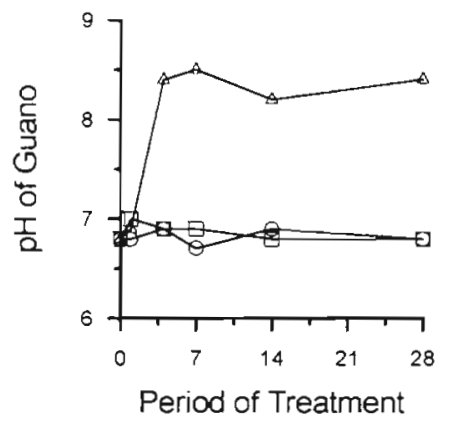

(Days)

Fig. 3. Anous minutus. Temporal changes in the $\mathrm{pH}$ of noddy guano in ambient (o), dry ( $\square$ ) and humid $(\Delta)$ atmosphere conditions (determined by adding $0.5 \mathrm{~g}$ guano to $100 \mathrm{ml}$ distilled and deionised water)

were estimated by scaling rates for noddies by 2.2 (see 'Methods').

\section{Guano input in 1992}

Estimates of guano deposited daily onto the island by noddies ranged from $738 \mathrm{~kg} \mathrm{~d}^{-1}$ (February 4) to $16 \mathrm{~kg}$ $\mathrm{d}^{-1}$ (June 26). The total deposition of fresh guano by noddies in 1992 was estimated to be $107.1 \mathrm{t}$.

Since the daily arrival and departure of shearwaters appears to be based on the rising and setting of the sun, we assumed their estimated daily input of guano increased accordingly as length decreased. Also, shearwaters were assumed to be absent from the island from May 17 until October 14. Given these assumptions, the estimated annual total input of fresh guano by shearwaters in 1992 was 21.2 t. Assuming guano of both species is similar in chemical composition, fresh guano deposited onto Heron Island in 1992 by both noddies and shearwaters amounted to $9.4 \mathrm{t}$ of nitrogen and $1.9 \mathrm{t}$ of phosphorus (Table 1).

Table 1 Anous minutus and Puffinus pacificus. Estimated inputs of nitrogen and phosphorus onto Heron Island, January to December 1992, from noddies, shearwaters, and human occupants of the resort and research station. Values in parentheses are percentages of total

\begin{tabular}{|lll|}
\hline Source & Total $\mathrm{N}(\mathrm{t})$ & Total P $(\mathrm{t})$ \\
\hline Noddies & $7.8(80.5)$ & $1.6(71.1)$ \\
Shearwaters & $1.6(16.5)$ & $0.3(14.6)$ \\
Resort & $0.20(2.1)$ & $0.29(12.9)$ \\
Research station & $0.09(0.9)$ & $0.03(1.3)$ \\
Total & $9.71(100.0)$ & $2.25(100.0)$ \\
\hline
\end{tabular}




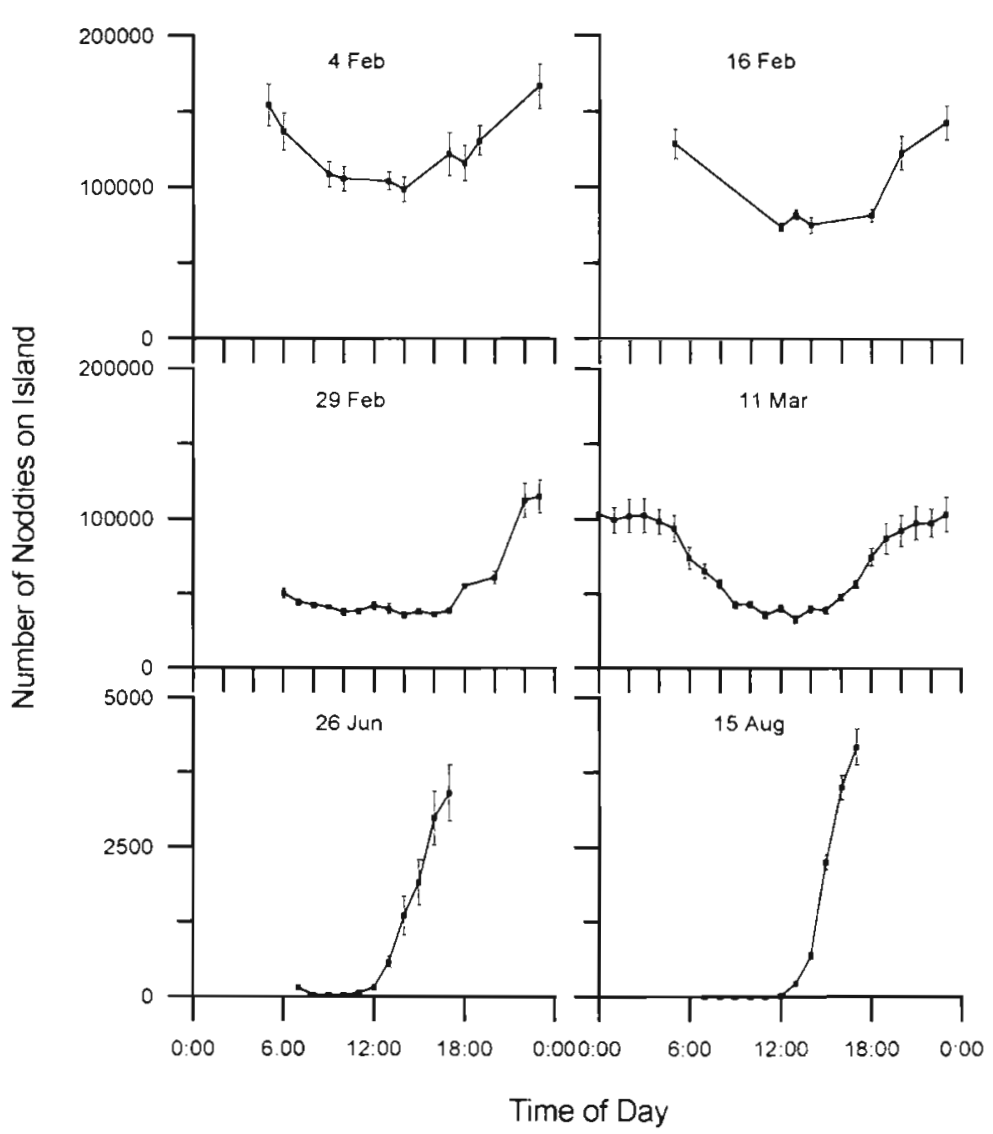

Fig. 4. Anous minutus. Diurnal changes in the number of noddies on Heron Island, 1992 (bars are \pm SE). Total populations were estimated as the number of birds on the island at 23:00 h. For times when night samples could not be made (June, August), total population was estimated as $1.4 \times$ (population at duskj (see 'Methods')
Tukey's HSD tests are not presented in detail in the interests of space, but overall trends are summarised as follows.

Overall, standing concentrations of OXN $\left(\mathrm{NO}_{2}+\mathrm{NO}_{3}\right), \mathrm{NH}_{3}$ and $\mathrm{PO}_{4}$ were significantly higher in summer than in winter, although the effect of season was often dependent on tide and distance from the island, i.e. zone (Table 4). In summer, concentrations of $\mathrm{NH}_{3}$ and $\mathrm{PO}_{4}$ were significantly higher at low tide than at high tide, but in winter concentrations of these nutrients were uniformly low irrespective of tide, therefore yielding significant season $\times$ tide interactions. Levels of $\mathrm{NH}_{3}$ and $\mathrm{PO}_{q}$ at the surface also demonstrated a zone $\times$ tide interaction; at high tide, concentrations $10 \mathrm{~m}$ from the island were higher than at sites further away (this trend was not significant for $\mathrm{PO}_{4}$ ), but at low tide, levels of nutrients closest to the island did not differ significantly from those across the reef flat and beyond the reef crest, which were comparable with the high tide values closest to the island. Analysis of data from Zones 1 and 2 only, which enabled testing of effects of rain, showed the same pattern, but only in summer, resulting in a zone $x$ tide $x$ season interaction.

There was no evidence that rain influenced concentrations of $\mathrm{NH}_{3}$ in the water

\section{Nutrient input from humans 1992}

Estimates of daily human input of TN and TP (based on daily occupancies, concentrations of $N$ and $P$ in effluent and effluent flow rates) between February and August varied from 255 to $802 \mathrm{~g} \mathrm{~d}^{-1}$ (resort) and 111 to $778 \mathrm{~g} \mathrm{~d}^{-1}$ (research station) for nitrogen, and 361 to $1135 \mathrm{~g} \mathrm{~d}^{-1}$ (resort) and 40 to $278 \mathrm{~g} \mathrm{~d}^{-1}$ (research station) for phosphorus. The estimated total input of nutrients from humans in 1992 (0.29 t nitrogen, $0.32 \mathrm{t}$ phosphorus) represents only 2.9 and $13.7 \%$ respectively of the total input of nitrogen and phosphorus from all sources (Table 1).

\section{Standing concentrations of nutrients in reef waters}

In examining effects of tide, season, rain (before vs after rain) and zone (distance from island) on the standing concentrations of nutrients (Tables $2 \& 3$ ), only significant results are presented (Table 4 ). The results of

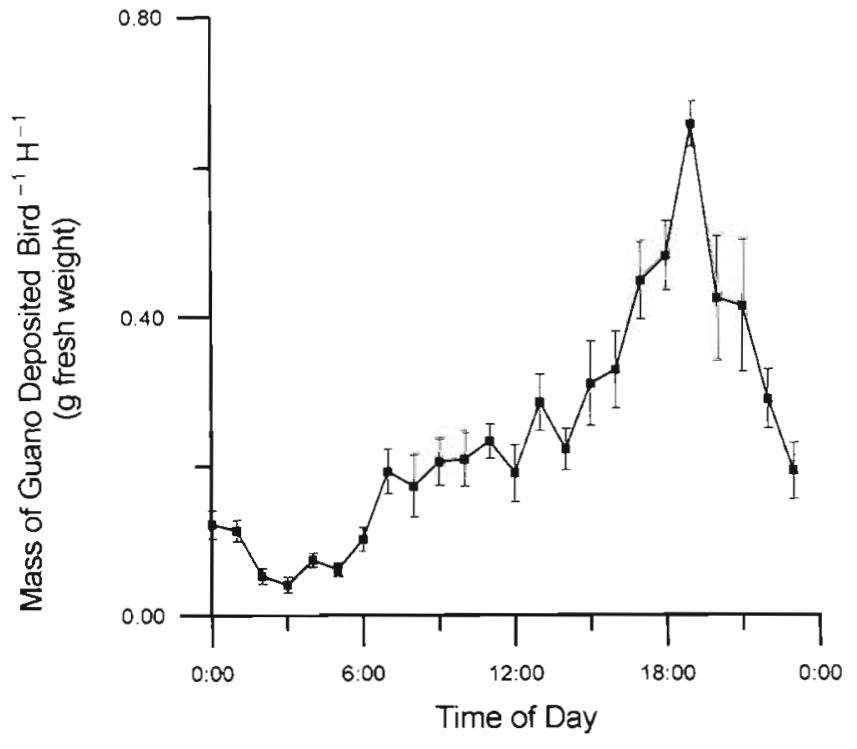

Fig. 5. Anous minutus. Diurnal variation in rates of defecation by noddies (data are means $\pm \mathrm{SE}$ of observations on $\mathrm{n}=$ 3 days) 

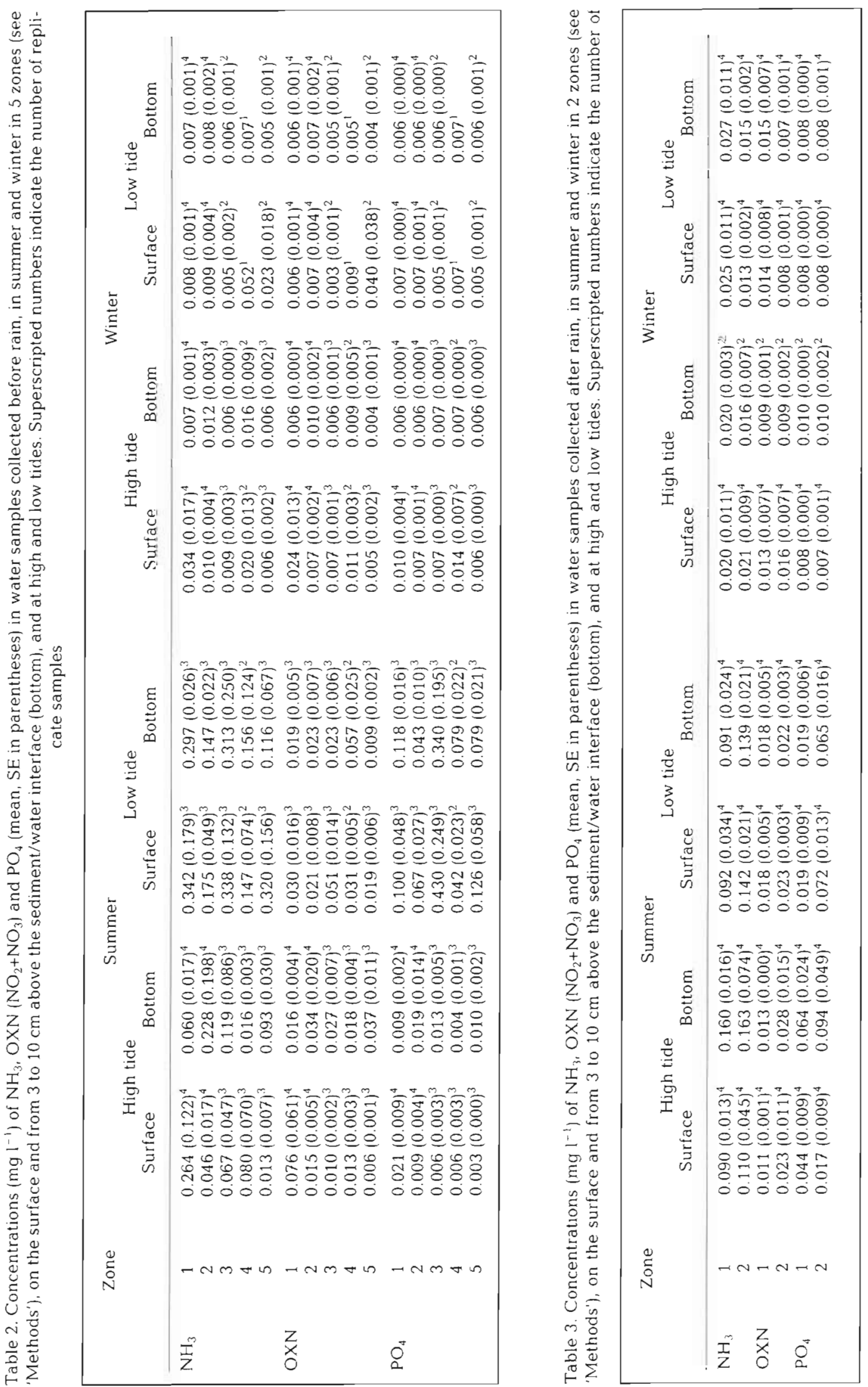


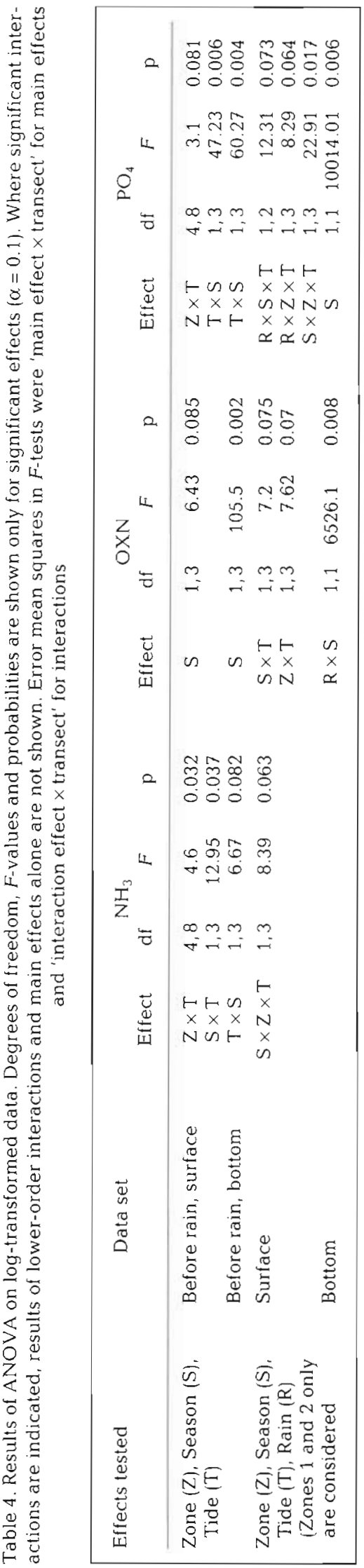

column around the island. However, concentrations of $\mathrm{PO}_{4}$ before rain at low tide were significantly higher than at high tide, but after rain, high tide and low tide values were not significantly different since levels at high tide were higher and at low tide were lower relative to levels before rain. However, this pattern was evident in summer only, with winter concentrations of $\mathrm{PO}_{4}$ uniformly low regardless of tide or the incidence of rain, resulting in a significant tide $\times$ rain $\times$ season interaction. It appears that the sensitivity of $\mathrm{PO}_{4}$ levels to rain only occurs close to the island (Zone $1=10 \mathrm{~m}$ from the beach), since in Zone $2(100 \mathrm{~m}$ from the beach) the typical pattern of higher concentrations at low tide than at high tide were not affected by rain.

\section{DISCUSSION}

Both human and bird populations on Heron Island, the 2 major sources of nutrients, have increased substantially over the past few decades. While plants on islands away from major land masses may depend on extraneous fertilisation (e.g. Lindenboom 1984), coral reefs surrounding coral cays are susceptible to changes in the status of nitrogen and phosphorus loadings (e.g. Smith et al. 1981). Therefore, there is interest in both the relative and absolute inputs of human- and bird-derived nutrients on Heron Island, and particular interest in the likelihood that the recent large increases in nutrient input will increase loadings in the water around the island, and possibly affect the reef community on the surrounding reef.

\section{Input of bird-derived nutrients}

The estimated input of guano from noddies during $1992(107.1 \mathrm{t}$ fresh $w t=42.9 \mathrm{t}$ dry $w \mathrm{t})$ was similar to that estimated by Allaway \& Ashford (1984) for 1983 (45 t dry wt), despite a $70 \%$ increase in the population of noddies over this time. Clearly there is a large discrepancy in the 2 estimates, particularly in that this study attempted to include the significant amount of guano intercepted by the foliage of Pisonia grandis trees but Allaway \& Ashford did not. We suggest that Allaway \& Ashford over estimated guano input for several reasons. First, their sampling was non selective and included guano from birds other than noddies, and material other than guano (e.g. feathers, plant material, and sand). Also, by sampling only in January and September, it is likely that the seasonal population minimum was missed. This might account for their estimate of only $23 \%$ seasonal variation in the mass of material deposited on the island, compared with our estimate of $98 \%$ seasonal variation. 
In addition to the guano deposited by noddies in 1992, an estimated 22.0 t fresh guano ( $=8.8 \mathrm{t}$ dry wt) was deposited by shearwaters. This estimate was based on the assumption of an allometric relationship with the defecation rate of noddies, and uses published data of seasonal and daily fluctuations in number of birds, but it is likely to be of the correct order.

\section{Fate of bird-derived nutrients}

Larkum et al. (1988) calculated a mean rate of nitrogen fixation at One Tree Reef, ca 3 nautical miles east of Heron Reef, of 8 to $16 \mathrm{~kg} \mathrm{ha}^{-1} \mathrm{yr}^{-1}$. Assuming a similar rate of fixation on Heron Reef, then the deposition of $9.4 \mathrm{t}$ of bird-derived nitrogen onto Heron Island in 1992, which equates to a rate of nitrogen input of $550 \mathrm{~kg} \mathrm{ha} \mathrm{hr}^{-1}$, is enormous by comparison. Add to this the deposition of $1.9 \mathrm{t}$ of bird-derived phosphorus onto an island surrounded by waters typically low in this element (D'Elia \& Wiebe 1990, this study), and Heron Island represents a significant, potential point source of nitrogen and phosphorus within the reef ecosystem. Whether this potential is ever realised depends on the fate of nutrients following deposition.

Direct runoff after heavy rain and leaching to groundwater with subsequent dispersal during tidal oscillations, are 2 mechanisms that can transport nutrients from terrestrial guano to surrounding seawater. Bosman \& Hockey (1986) found that of the total nutrients released from fresh seabird guano dissolved in water for $24 \mathrm{~h}$, less than $8 \%$ was released by $12 \mathrm{~mm}$ of artificial rain, and for aged guano the amount was less than $1 \%$. These results suggest that significantly more than $12 \mathrm{~mm}$ of rain is needed to leach as little as onequarter of the soluble nutrients from guano. On most occasions less than $10 \mathrm{~mm}$ of rain falls in a $24 \mathrm{~h}$ period at Heron Island, even in the summer wet season (longterm averages; Bureau of Meteorology 1991, 1992), so that only a small fraction of the soluble nutrients in guano could be expected to leach within a $24 \mathrm{~h}$ period. The question arises as to the fate of nutrients remaining in the guano.

\section{Volatilisation of ammonia}

We showed experimentally that humid conditions which are associated with rainfall, cause at least a $58 \%$ loss of total initial nitrogen in guano within $4 \mathrm{~d}$ of deposition. A humid atmosphere promotes decomposition of organic nitrogen to $\mathrm{NH}_{3}$, with subsequent loss of $\mathrm{NH}_{3}$ through volatilisation. Accelerated losses of $\mathrm{NH}_{3}$ in humid compared with drier atmospheres is probably attributable to the higher $\mathrm{pH}$ of guano in humid condi- tions (Fig. 3; Rump \& Krist 1988). It is likely that under natural conditions loss of nitrogen from volatilisation of $\mathrm{NH}_{3}$ occurs more rapidly than is indicated by our estimates, since in the summer wet season rainfall and wind usually occur together. In the last $20 \mathrm{yr}$, over onethird of days between January and July experienced rainfall (Bureau of Meteorology 1992). Thus, it is likely that most of the organic nitrogen in fresh guano deposited during the wet season is soon lost as $\mathrm{NH}_{3}$, i.e. this pathway represents the single largest flux of deposited nitrogen. However, not all volatilised $\mathrm{NH}_{3}$ is lost from the system since atmospheric $\mathrm{NH}_{3}$ dissolves in rain (Lindenboom 1984). In this way some amount of nitrogen will be returned to the island and surrounding waters, depending on wind intensity prior to and during periods of rain.

\section{Nitrification}

Ammonia oxidised to leachable $\mathrm{NO}_{2}$ and $\mathrm{NO}_{3}$ is no longer susceptible to volatilisation, although under anaerobic conditions it may be reduced to nitrogen gas (denitrification) and lost to the atmosphere (Riley \& Chester 1971). Nitrification during dry periods will increase the proportion of nitrogen that leaches and decrease the proportion that volatilises.

In summary, the amount of nitrogen from guano lost as $\mathrm{NH}_{3}$ gas, leached into the cay, or which remains in solid form above ground depends on rainfall and humidity. If heavy rain does not fall soon after deposition then only a relatively small proportion of the nitrogen in the fresh guano will leach into the cay. The exact quantity of leached nitrogen will be determined by several factors. Frequent falls of small volumes of rain will cause most of the organic nitrogen to be decomposed to $\mathrm{NH}_{3}$ and volatilise rapidly, and only a small percentage will leach into the island. If strong winds precede and accompany rainfall, a percentage of atmospheric $\mathrm{NH}_{3}$ will return to the cay but most will be deposited away from the reef. During periods without rain, ammonification and nitrification will form compounds that remain in the soil until they are absorbed by plants or leach with rain. Estimating these processes for a given period on Heron Island will require careful monitoring of rainfall, wind and humidity, and further experimentation.

\section{Phosphorus}

Unlike nitrogen, no substantial changes in total phosphorus levels in guano were observed over $28 \mathrm{~d}$ after deposition under experimental conditions. This suggests that leaching of the soluble phosphorus com- 
ponent of guano $\left(\mathrm{PO}_{4}\right)$ by rain is the only significant transport mechanism. However, given the high affinity of phosphate to bind with the parent material $\left(\mathrm{CaCO}_{3}\right)$ of the cay (Furnas 1990), leaching of phosphorus into the porous cay does not necessarily imply transport to reef waters.

\section{Input of sewage}

Approximately $0.3 \mathrm{t}$ of both nitrogen and phosphorus was introduced to the cay system in 1992 from the resort and research station, amounting to ca 3 and $14.2 \%$ of the total input of nitrogen and phosphorus respectively. However, in contrast to the need for rain to transport nutrients from guano to groundwater, nutrients from the sewage plant and septic systems are released in liquid form so that their transport to groundwater occurs continuously. Krol et al. (1992) measured high concentrations of $\mathrm{NH}_{3}$ in a well situated close to the soakaway of the sewage plant after an extensive period without rain. Although they found that nitrification and dilution by $\mathrm{NO}_{3}$-rich groundwater decreased the concentration of $\mathrm{NH}_{3}$ with depth, the levels of $\mathrm{NH}_{3}$ suggested that a substantial portion of the effluent reaches the deep groundwater in the absence of rain.

\section{Is there transport of nutrients to surrounding reef waters?}

Given continuous supply of nutrients from sewage to groundwater, and the high likelihood of seasonal transport of bird-derived nutrients (unknown amounts) to groundwater with rain, release of terrestriallydeposited nutrients to surrounding waters may occur through the mechanisms of tidal pumping and/or heavy rainfall. Certainly, concentrations of both $\mathrm{NH}_{3}$ and $\mathrm{PO}_{4}$ are elevated in the island groundwater (P. Bell \& A. Krol, unpubl. data).

Despite interaction effects that qualified some results, our analyses of standing concentrations of nutrients in reef waters demonstrated 2 patterns consistent with release of nutrients from the island. First, concentrations of $\mathrm{NH}_{3}, \mathrm{OXN}$ and $\mathrm{PO}_{4}$ were consistently and significantly higher in summer than in winter, correlating with the period of high input of nutrients onto the island by birds. Although the correlation may underscore a causal mechanism, an alternative explanation is that the summer increase is independent of elevated deposition rates of bird-derived nutrients, but reflects seasonal variation in biological activity on the reef and in mechanisms of resuspension of sediment nutrients (see D'Elia \& Wiebe 1990). It is noteworthy that the seasonal pattern was largely independent of the incidence of rain, the exception being that levels of $\mathrm{PO}_{4}$ were sensitive to rain, but only in summer and in the zone closest to the island.

The other general pattern was that, in summer, nutrient levels at high tide were significantly lower than those at low tide except close to the island where they remained high irrespective of tide. We interpret this to reflect dilution of the relatively nutrient-rich water that accumulates over the reef flat at low tide with influx of nutrient-poor inter-reefal water as the tide rises. However, the significant trend that nearshore levels of $\mathrm{NH}_{3}$ and $\mathrm{PO}_{4}$ remain high at high tide (in most cases), despite strong water currents in depths of ca $2 \mathrm{~m}$ effecting water exchange at the sample sites at high tide, suggests that nutrients may emanate from the island.

Measurement of standing concentration of nutrients is a coarse technique for detecting changes in nutrient loading since increases in loading may not generate a signal in concentration given rapid uptake of nutrients by microalgae and bacteria (Valiela 1984). That our investigation detected significant changes in nutrient concentrations consistent with transport of nutrientrich groundwater to reefal water may indicate a significant but localised nutrient loading from the island. However, questions of connectivity between groundwater and reef water, rates of transport of leached nutrients after rain, and the potential impact of increased nutrient loading on the reef community deserve further attention.

Acknowledgements. We thank Louise Ellingham for help throughout, Jim Charley for providing us with his unpublished report on nutrient dynamics on coral cays, John Ogden for providing unpublished data on noddy and shearwater populations, Andrew Beck and Timothy Ault for assistance in the field, P\&O Resorts for ferry transport, the staff of The Heron Island Research Station and Mike Wrighton for information on the history of Heron Island sewage treatment. We are grateful to Don Kinsey and Stephen Smith for constructive criticism of the manuscript. Thanks also to André Krol, Delton Chen and Peter Bell for input and discussion of their unpublished data from the Heron Island Groundwater Project. The work was supported by grants to C. R.J. from the Great Barrier Reef Marine Park Authority and The University of Queensland.

\section{LITERATURE CITED}

Allaway WG, Ashford AE (1984) Nutrient input by seabirds to the forest on a coral island of the Great Barrier Reef. Mar Ecol Prog Ser 19:297-298

Anon (1992a) Heron Island plant performance, February 1992. Report to P\&O Resorts. Simmonds and Bristow Pty Ltd, Brisbane

Anon (1992b) Heron Island plant performance, March 1992. Report to P\&O Resorts. Simmonds and Bristow Pty Ltd, Brisbane 
Barnes A, Hill GJE (1989) Census and distribution of black noddy Anous minutus nests on Heron Island, November 1985. Emu 89:129-134

Bédard J, Therriault JC, Bérubé J (1980) Assessment of the importance of nutrient recycling by seabirds in the $\mathrm{St}$. Lawrence Estuary. Can J Fish Aquat Sci 37:583-588

Bell PRF (1992) Eutrophication and coral reefs - some exam. ples in the Great Barrier Reef Lagoon. Wat Res 26:553-568

Bosman AL, Du Toit JT, Hockey PAR, Branch GM (1985) A field experiment demonstrating the influence of seabird guano on intertidal primary production. Estuar coast Shelf Sci 23:283-294

Bosman AL, Hockey PAR (1986) Seabird guano as a determinant of rocky intertidal community structure. Mar Ecol Prog Ser 32:247-257

Bureau of Meteorology (1991/1992) Australian data archives for meteorology. Bureau of Meteorology. Brisbane

Canter LW, Knox RC (1985) Septic system effects on groundwater quality. Lewis Publishers, Inc, Michigan

Copeman PR, Dillman FJ (1937) Changes in the composition of guano during storage. J Agric Sci 27:178-187

Day RW, Quinn GP (1989) Comparison of treatments after an analysis of variance in ecology Ecol Monogr 59:433-463

D'Elid CF, Wiebe WJ (1990) Biogeochemical nutrient cycles in coral-reef ecosystems. In: Dubinsky $Z$ (ed) Ecosystems of the world 25: coral reefs. Elsevier, Amsterdam, p 49-74

Furnas MJ (1988) Water column nutrient processes in Great Barrier Reef waters. In: Baldwin CL (ed) Workshop on mutrients in the Great Barrier Reef region. Great Barrier Reef Marine Park Authority, Townsville, p 45-54

Furnas MJ (1990) The behavior of nutrients in tropical aquatic ecosystems. In: Connell DW, Hawker DW (eds) Pollution in tropical aquatic systems. CRC Press, London, p 30-65

Hill GJE, Barnes A (1989) Census and distribution of wedgetailed shearwater Puffinus pacificus burrows on Heron Island, November 1985. Emu 89:135-139

Hutchinson GE (1950) Survey of contemporary knowledge of biogeochemistry. 3. The biogeochemistry of vertebrate excretion. Bull Am Mus Nat Hist 96:1-554

Kelleher G (1988) Opening address. In: Baldwin CL (ed) Workshop on nutrients in the Great Barrier Reef region. Great Barrier Reef Marine Park Authority, Townsville, p $1-1.0$

Kikkawa J (1970) Birds recorded at Heron Island. Sunbird 1 $34-47$

Kinsey DW (1988) Responses of coral reef systems to elevated nutrient levels. In: Baldwin CL (ed) Workshop on nutrients in the Great Barrier Reef Region. Great Barrier Reef Marine Park Authority, Townsville, p 55-65

This article was presented by D. M. Alongi (Senior Editorial Advisor), Townsville, Australia
Kinsey DW, Davies PJ (1979) Effects of elevated nitrogen and phosphorus on coral reef growth. J Am Soc Limnol Oceanogr 24:935-940

Krol A, Noordink M, Jell J, Chen D (1992) The Heron Island groundwater project. Proc 1992 Nat Conf Environ Engin, Gold Coast, Institute of Australian Engineers, Canberra

Larkum AWD, Kennedy IR, Muller WJ (1988) Nitrogen fixation on a coral reef. Mar Biol 98:143-155

Lindeboom $\mathrm{HJ}$ (1984) The nitrogen pathway in a penguin rookery. J Ecol 65:269-277

Ogden J (1979) Estimates of the population sizes of the black noddy and wedge-tailed shearwater at Heron Island in 1978. Sunbird 10:33-39

Ottesen P (1988) Managing for the effects of increased activities in the Great Barrier Reef Marine Park. Great Barrier Reef Marine Park Authority Staff Paper 8813, Townsville

Peters RH (1983) The ecological implications of body size Cambridge University Press, New York

Prove B (1988) Soil erosion research in cane fields on the wet tropical coast of north-east Queensland. In: Baldwin CL (ed) Workshop on nutrients in the Great Barrier Reef region. Great Barrier Reef Marine Park Authority, Townsville, p 30-32

Rasmussen C (1988) Effects of nutrients carried by mainland run-off on reefs on the Cairns Area: a research plan and preliminary results. In: Baldwin CL (ed) Workshop on nutrients in the Great Barrier Reef region. Great Barrier Reef Marine Park Authority, Townsville, p 66-91

Riley JP, Chester R (1971) Introduction to marine chemistry Academic Press, Liverpool, p 152-179

Rump HH, Krist $H$ (1988) Laboratory manual for the examintation of water, waste water and soil. VCH Publishers New York

Science and Engineering Research Council (1992) The star almanac for land surveyors for the year 1992. Her Majesty's Statistical Office, London

Serventy DL, Serventy VN, Warnham J (1971) Handbook of Australian sea-birds. Reed, Sydney

Smith SV, Kimmerer WJ, Laws EA, Brock RE, Walsh TW (1981) Kaneh oe Bay sewage diversion experiment: perspectives on ecosystem responses to nutritional perturbation. Pacif Scl 35:279-285

Valiela I (1984) Marine ecological processes. Springer, Berlin, p $312-335$

Wilkinson CR (1993) Coral reefs of the world are facing widespread devastation: can we prevent this through sustainable management practices? Proc 7th int Coral Reet Symp $1: 11-21$

Manuscript first received: June 9, 1994

Revised version accepted: February 7, 1995 